\title{
KETERKAITAN BUDAYA SEKOLAH DENGAN KINERJA GURU PENDIDIKAN AGAMA HINDU
}

\author{
I Gusti Lanang Jelantik \\ Universitas Hindu Indonesia \\ Denpasar
}

\begin{abstract}
Hindu religious education teachers have the responsibility of implementing the national education system in realizing the goals of national education. To realize these responsibilities, teachers are required to have high performance. A teacher may not perform high in carrying out her responsibilities, if not supported by her school culture. The school culture is concerned with norms, behaviors, values, philosophies, ideologies, assumptions held by stakeholders in schools. More and more schoolchildren who accept these values of school culture are stronger, strongly influencing teacher behavior, because of the high level of togetherness and intensity that will create an internal climate of professional behavior control. School culture into a social glue unites teachers and other stakeholders in implementing national education standards to improve teacher performance.
\end{abstract}

Keywords: education, culture, performance.

\begin{abstract}
Abstrak
Guru pendidikan agama Hindu memiliki tanggung jawab sebagai pelaksana sistem pendidikan nasional dalam mewujudkan tujuan pendidikan nasional. Untuk mewujudkan tanggung jawab tersebut, guru dituntut memiliki kinerja yang tinggi. Seorang guru tidak mungkin berkinerja tinggi dalam melaksanakan tanggung jawabnya, jika tidak didukung oleh budaya sekolahnya. Budaya sekolah adalah berkenaan dengan norma-norma, perilaku, nilai-nilai, filosofis, ideologi, asumsi-asumsi yang dimiliki oleh stakeholder di sekolah. Makin banyak warga sekolah yang menerima nilai-nilai tersebut budaya sekolah semakin kuat, sangat berpengaruh terhadap perilaku guru, karena tingginya tingkat kebersamaan dan intensitas yang akan menciptakan iklim internal atas pengendalian perilaku yang profesional. Budaya sekolah menjadi perekat sosial mempersatukan para guru dan stakeholder yang lain dalam mengimplementasikan standar pendidikan nasional untuk meningkatkan kinerja guru.
\end{abstract}

Kata Kunci: pendidikan, budaya, kinerja. 


\subsection{Pendahuluan}

Mencermati proses pendidikan dari segi budaya hakekatnya sama dengan posisi pendidikan sebagai jaringan praktek kehidupan sosial budaya yang komplek dari satu masyarakat. Hal ini menunjukkan bahwa proses pendidikan di satu sisi terlaksananya praktek-praktek pembelajaran di lembaga sekolah, tetapi disisi lain, proses pendidikan menyangkut berbagai kehidupan yang secara umum sering disebut sebagai proses kebudayaan. Hakekat pendidikan tidak bisa lepas dari hakekat manusia sebagai mahluk berpikir yang mampu hidup dan berkembang melalui proses belajar. Meskipun manusia memiliki naluri dalam menjaga dan mempertahankan kehidupannya. Tetapi berbeda dengan hewan pada umumnya, manusia tidak mampu hanya bertahan dengan kelengkapan naluri saja. Disini diperlukan satu proses pengembangan diri (fisik maupun mental) dengan bimbingan orang lain (guru) yang disebut proses pembelajaran atau proses pendidikan. Manusia memiliki kemampuan mengembangkan berbagai potensi dirinya untuk mengembangkan daya cipta, rasa, karsa dan karya yang menjadi inti proses budaya.

Dengan demikian sangat tepat proses pendidikan direncanakan sebagai proses berdimensi kultural artinya pendidikan sebagai sarana proses pembudayaan atau sering diistilahkan sebagai proses harmonisasi (pemanusiaan manusia). Semua hal tersebut bisa dikatakan bahwa proses pendidikan, khususnya proses belajar tidak bisa dipisahkan dengan kehidupan manusia dalam rangka penciptaan budaya sekaligus pewarisannya kepada generasi muda. Dalam hubungan inilah kita bicara tentang keterkaitannya ada interrelasi sensitif, artinya pertambahan yang satu harus diimbangi oleh pertumbuhan lainnya yang diharapkan memiliki potensi saling dukung dalam rangka meningkatkan hakekat dan martabat manusia (Widja, 2012:11).

Dalam proses pendidikan di sekolah sangat penting mencermati faktor-faktor lingkungan yang terkait dengan kemampuan adaptif anak sangat penting diperhatikan, terutama dalam tahapan pembentukan kepribadian anak. Sebagai konsekuensinya para pendidik (guru) sangat penting memperhitungkan aspek-aspek latar budaya yang ikut menentukan dan mewarnai motifmotif perilaku anak didik.

Budaya yang berkembang di lingkungan masyarakat lokal yang bersumber dari keyakinan agama, adat istiadat, tradisi, hubungan kekerabatan dan komunikasi antar individu serta etika. Kehidupan lokal dapat dijadikan nilai sebagai visi sekolah yang akan dirumuskan dan ditetapkan di sekolah. Peran budaya lokal dapat menciptakan budaya organisasi dan budaya kerja (work culture) sekolah melalui nilai-nilai, misi, tujuan-tujuan strategis, kebijakan dan program-program sekolah yang ditetapkan dengan disepakati bersama. Sehingga budaya organisasi sekolah yang mengakomodasi budaya lokal yang konstruktif dapat memberikan arah dan pedoman berperilaku di sekolah. Setiap anggota yang berkepentingan dengan organisasi sekolah (stakeholders) mempunyai kesamaan langkah mewujudkan visi sekolah dalam melakukan tugas dan tanggung jawab sehingga individu dapat berperan serta meningkatkan professionalismnya, mengembangkan interdependensi, dan kerja sama secara terkoordinasi dan terpadu antar individu secara lebih efisien dan produktif dapat saling melengkapi dalam upaya mengembangkan organisasi serta mendorong stakeholder agar konsisten dengan tugas profesi, wewenang dan tanggung jawabnya.

Kebijakan decentralisasi dan otonomi 
pendidikan berdampak positif terhadap sekolah, karena pendidikan secara azasi dikembalikan kepada masyarakat yang dikelola oleh sekolah sebagai pusat budaya. Proses pendidikan sesungguhnya adalah proses pembudayaan yang kongkrit, karena proses pendidikan tidak dapat terlepas dari transfer nilai-nilai dan bagian yang terpadu dari kebudayaan (Widja, 2012). Desentralisasi dengan otonomi pendidikan merancang proses pendidikan agar bertolak dari kebudayaan lokal dimana proses pendidikan tersebut berlangsung. Paradigma ini menuntut adanya manajemen pendidikan yang menumbuh kembangkan suatu sistem pendidikan berakar dari kebudayaan baik lokal maupun nasional dalam suatu masyarakat daerah yang konkrit sebagai pemiliknya.

Kepala sekolah, guru dan stakeholder yang lain harus menciptakan budaya sekolah dan menyadari bahwa hal itu tidak lepas dari struktur dan fungsi manajemen sekolah, perubahan budaya yang lebih sehat harus dimulai dari guru sebagai pendidik. Guru harus mengembangkan pendidikan yang berkualitas, bermutu dan demokratis, saling perhatian dan pengertian satu dengan yang lain. Hasil penelitian pengaruh budaya sekolah terhadap prestasi belajar siswa di Amerika Serikat dalam (Rika, 2011 : 168) telah dibuktikan secara empiris. Budaya yang "sehat" memiliki korelasi yang tinggi dengan (1) prestasi dan motivasi siswa untuk berprestasi, (2) sikap dan motivasi kerja guru, dan (3) produktivitas dan kepuasan kerja guru.

Dengan demikian para guru termasuk guru pendidikan agama Hindu diharapkan mampu menciptakan budaya sekolah melalui proses belajar agar kinerja manajemen sekolah meningkat dan kualitas serta mutu pendidikan di sekolah secara bertahap mengalami peningkatan. Guru pendidikan agama Hindu dapat mengelola "kompetensi" dirinya dalam melaksanakan pembelajaran agama Hindu untuk membentuk peserta didik menjadi manusia yang beriman dan bertakwa kepada Tuhan Yang Maha Esa dan berakhlak mulia serta peningkatan potensi spiritual. Akhlak mulia mencakup etika, budi pekerti, dan moral sebagai perwujudan dari pendidikan agama Hindu. Peningkatan potensi spiritual mencakup pengenalan, pemahaman dan penanaman nilai-nilai keagamaan, serta pengamalan nilai-nilai tersebut dalam kehidupan individu ataupun kolektif kemasyarakatan, yang pada akhirnya bertujuan pada optimalisasi berbagai potensi yang dimiliki manusia yang aktualisasinya mencerminkan harkat dan martabatnya sebagai makhluk Tuhan.

Hal tersebut mengandung makna bahwa pendidikan agama Hindu diarahkan untuk membangun kualitas mental pribadi peserta didik agar memiliki visi yang jelas, wawasan dan pengetahuan kontekstual, tujuan hidupnya jelas, komitmen terhadap nilai-nilai, kemampuan hidup secara harmonis, dan kreatif sesuai budaya yang berkembang dalam masyarakat yang pluralistis, dan kepedulian terhadap lingkungan. Hal tersebut ditegaskan dalam peraturan pemerintah nomor 55 Tahun 2007 tentang Pendidikan Agama dan Pendidikan Keagamaan dinyatakan sebagai berikut :

Pendidikan agama berfungsi membentuk manusia Indonesia yang beriman dan bertakwa kepada Tuhan Yang Maha Esa serta berakhlak mulia dan menjaga kedamaian dan kerukunan hubungan inter dan antar umat beragama. Dan bertujuan untuk berkembangnya kemampuan peserta didik dalam memahami, menghayati, dan mengamalkan nilai-nilai agama yang menyerasikan penguasaan dalam ilmu pengetahuan, teknologi dan seni.

Mencermati fungsi dan tujuan 
pendidikan agama di atas guru pendidikan agama Hindu sebagai pelaksana utama pengelola proses pembelajaran pada satuansatuan pendidikan dituntut memiliki kemampuan profesional dan kinerja yang memadai untuk mewujudkan fungsi dan tujuan pendidikan agama tersebut.

\subsection{Pembahasan}

Kini kondisi ideal tersebut yang menjadi harapan masyarakat telah mengalami banyak perubahan sebagai akibat pergeseran nilai-nilai dan normanorma akibat situasi global. Suatu kondisi perubahan perkembangan ilmu pengetahuan dan teknologi informasi yang berdampak pada perubahan perilaku kehidupan yang tak kuasa mengelak apalagi menolak arus perubahan dengan berbagai akses, terutama yang cenderung menghancurkan normanorma maupun nilai-nilai ideal akibat pengaruh peradaban baru, dengan kebudayaan kontemporer yang semakin sekulker menggerus mental, moral, spiritual masyarakat Hindu sehingga kecenderungan bergaya hidup materialistis dan hedomistis. Hal ini juga disampaikan oleh Suyanto (2001 : 6) menyatakan bahwa, pendidikan di semua jenjang sampai saat ini, lebih mementingkan aspek kognitif, sedangkan aspek afektif seperti sikap, minat, motivasi berprestasi, empati, toleransi, kecerdasan emosional, dan spiritual sistem nilai sangat terlantarkan.

Efek kondisi ini, sepertinya telah terjadi degradasi atau dekadensi terhadap aspek-aspek moralitas yang sebenarnya sangat dibutuhkan dalam kerangka membangun kekuatan manusia yang berkarakter unggul (suputra). Atas dasar kondisi tersebut, diperlukan adanya strategi pendidikan yang berkemampuan membangun moralitas, melalui upaya-upaya persuasif dengan pendekatan pedagogis, sosiologis, psikologis dan religius untuk menghasilkan output yaitu SDM yang memiliki karakter.

Pemerintah bersama masyarakat penting sekali dikonstruksi dan dikembang suatu lembaga pendidikan atau sekolah yang menjunjung tinggi nilai-nilai budaya. Karena budaya sekolah yang kuat memperlihatkan kesepakatan yang tinggi di kalangan guru-guru untuk meningkatkan kinerja dalam upaya meningkatkan mutu pendidikan. Hal ini telah dibuktikan di Amerika Serikat bahwa budaya sekolah sangat berpengaruh terhadap kinerja guru. Budaya yang "sehat" memiliki korelasi yang tinggi dengan sikap dan motivasi kerja guru, dan produktivitas serta kepuasan kerja guru (dalam Rika, 2011 : 168).

Hasil penelitian Jelantik (2015 : 407) pada SMP Negeri se Bali menunjukkan bahwa ada hubungan yang signifikan dan korelasi positif antara budaya sekolah dengan kinerja guru pendidikan agama Hindu. Koefisien korelasi kedua variabel adalah 0,153 . Hal ini menunjukkan bahwa budaya sekolah berpengaruh terhadap kinerja guru pendidikan agama Hindu. Hal ini juga diperkuat dengan temuan penelitian Ting (1997) menemukan bahwa budaya organisasi sangat mempengaruhi kepuasan kerja dan kinerja guru. Selanjutnya penelitian yang dilakukan Ogboma dan Harris (2000) menemukan ternyata budaya organisasi merupakan mediator antara kepemimpinan terhadap kinerja karyawan.

Arikunto (1998 : 35) menjelaskan tentang budaya sekolah, bahwa unsur-unsur budaya sekolah meliputi tradisi-tradisi dan kebiasaan-kebiasaan sekolah, pengalaman, sejarah, pengertian-pengertian yang terucap, norma-norma, harapan-harapan dan asumsiasumsi bersama. Semakin budaya itu dimengerti, diterima dan dianggap merupakan suatu kesatuan kesadaran, maka akan semakin mudah pulalah usaha untuk meningkatkan kinerja guru. Guna mencapai 
tujuan yang dikehendaki.

Berdasarkan uraian tersebut diatas dapat disimpulkan bahwa budaya sekolah dapat mempengaruhi kinerja guru pendidikan agama Hindu di sekolah.

\section{Budaya Sekolah}

Setiap organisasi memiliki budaya organisasi (organization culture) dan Iklim organisasi (organization climate) merupakan dua hal yang saling berhubungan antara satu dengan yang lainnya. Menurut Owens (1991) budaya menunjuk pada norma-norma perilaku, asumsi-asumsi, dan keyakinan mengenai organisasi, sedangkan iklim menunjuk pada persepsi orang-orang dalam organisasi yang merefleksikan normanorma, asumsi-asumsi, dan keyakinankeyakinan tersebut. Demikian pula budaya sekolah merupakan kepribadian sekolah yang diwujudkan melalui nilai dan keyakinan anggota organisasi.

Budaya sekolah juga harus dilihat sebagai bagian suatu kesatuan sekolah yang utuh. Artinya, suatu yang ada pada suatu budaya sekolah hanya dapat dilihat dan dijelaskan dalam kaitan dengan aspek yang lain, seperti : a) rangsangan untuk berprestasi, b) penghargaan yang tinggi terhadap prestasi, c) komunitas sekolah yang tertib, d) pemahaman tujuan sekolah, e) ideology organisasi yang kuat, f) partisipasi orang tua siswa, g) kepemimpinan kepala sekolah dan h) hubungan akrab di antara warga sekolah (Rika, 2011).

Kepala sekolah harus memahami budaya sekolah yang ada, dan menyadari bahwa hal itu tidak lepas dari struktur dan pola kepemimpinannya. Perubahan budaya yang lebih sehat harus dimulai dari kepemimpinan kepala sekolah. Kepala sekolah harus mengembangkan kepemimpinan berdasarkan dialog, saling perhatian dan pengertian satu dengan yang lainnya. Biarlah guru, staf administrasi bahkan siswa menyampaikan pandangannya tentang budaya sekolah yang ada dewasa ini, mana segi positif dan mana segi negatifnya khususnya yang berkaitan dengan kepemimpinan kepala sekolah, struktur organisasi, nilai-nilai, normanorma, kepuasan terhadap kelas dan produktivitas.

Berdasarkan hal tersebut di atas dapat dipahami bahwa jika civitas akademika sekolah menerima dan mengerti budaya mereka maka tujuan yang akan dicapai dapat dengan mudah dicapai. Dalam pencapaian tujuan tersebut sangat dipengaruhi oleh spirit masing-masing komponen dalam civitas akademika sekolah. Jika spirit yang dimiliki tertanam dengan baik dalam masing-masing individu yang ada, maka sebaik apapun dan sekuat apapun budaya yang ada maka tujuan yang ingin dicapai akan sulit sekali dicapai.

Usaha-usaha dalam penanaman dan pemantapan spirit kepada seluruh civitas akademika sekolah menjadi tanggung jawab bersama. Kepala Sekolah dan jajaran Wakil Kepala Sekolah memegang peranan yang cukup sentral dalam menumbuhkan spirit kepada seluruh civitas akademika sekolah karena Kepala Sekolah dan jajaran Wakil Kepala Sekolah memiliki wewenang yang besar. Selain memiliki wewenang yang besar, Kepala Sekolah dan jajaran Wakil Kepala Sekolah memiliki pengaruh yang cukup besar kepada seluruh komponen yang terkait dengan budaya sekolah (siswa, guru, karyawan dan orang tua wali Murid).

Selanjutnya norma dapat dipahami sebagai seperangkat ketentuan yang berlangsung secara alami atau ditetapkan oleh suatu kelompok untuk ditaati bersama. Norma dapat berupa kebiasaan, adat-istiadat dan peraturan (Owens, 1991). Norma dapat menjadi referensi anggota dalam berpikir dan bertindak tentang apa yang akan dicapai di sekolah. Itulah sebabnya, sekolah 
memiliki norma akan melahirkan karakteristik budaya organisasi yang berkualitas.

Sekolah memiliki budaya yang dapat dilihat dari kemampuan sekolah untuk menciptakan seperangkat norma sebagai acuan anggota organisasi dalam berperilaku di sekolah. Kepala sekolah, guru, siswa, karyawan dan pihak lainnya tanpa norma yang tertanam dalam aktivitas sehari-hari maka akan sulit untuk mencapai tujuan organisasi secara efektif dan efisien. Di sinilah kepala sekolah dituntut untuk membangun norma sekolah agar tercipta budaya sekolah yang mendukung pencapaian kinerja guru.

Seperangkat peraturan sekolah merupakan bentuk norma yang terorganisir dalam suatu organisasi sekolah. Peraturan baik yang tertulis maupun yang tidak tertulis merupakan bagian dari norma sekolah, yang merupakan budaya sekolah. Semakin tinggi norma yang ditetapkan dalam sekolah, maka ia akan terbangun budaya yang berkualitas.

Dyer seperti yang dikutip Sergiovanni et al (1987 dan 1992) menyebutkan ada empat tingkat budaya ialah artefak, perspektif, nilai, dan asumsi. Keempat tingkat budaya ini disebut sebagai dimensi budaya organisasi. Sedangkan model tingkat budaya Schein seperti yang dikutip Owens (1991) adalah artefak dan kreasi, nilai dan asumsi dasar. Dari kedua pendapat ini tampak tingkat budaya organisasi mencakup artefak dan kreasi, perspektif, nilai dan asumsi.

Dengan demikian dapat disimpulkan tingkatan budaya sekolah meliputi artefak dan kreasi, perspektif, norma, nilai dan asumsi. Keempat tingkat itu sebenarnya mencerminkan tingkat kekongkritan dan tingkat keabstrakan atau tingkat kedangkalan dan tingkat kedalaman (Hoy dan Miskel, 1987). Jadi tingkat budaya sekolah yang paling abstrak atau dalam ialah asumsi, sedangkan yang paling konkrit atau dangkal ialah artifak dan kreasi.

Stolp dan Smith (1995), membagi budaya menjadi tiga lapisan yaitu; artifak di permukaan, nilai-nilai dan keyakinan di tengah, dan asumsi di dalam, seperti pada gambar berikut ini.

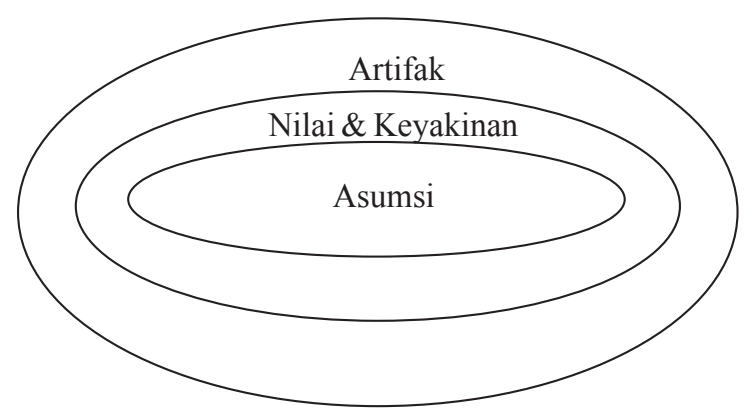

Gambar. Lapisan-lapisan Budaya Sekolah

Artifak adalah budaya sekolah yang segera dan paling mudah untuk diamati, didengar dan dirasakan seperti : aneka ritual sehari-hari di sekolah, berbagai upacara, benda-benda di sekolah dan aneka ragam kebiasaan yang berlaku di sekolah serta perilaku stakeholders di sekolah. Lapisan budaya sekolah yang lebih dalam berupa nilai-nilai dan keyakinan-keyakinan yang didukung, merupakan hal-hal yang berharga untuk dikerjakan atau menjadi alasan seseorang mengapa mau mengerjakan sesuatu. Artinya, nilai-nilai yang didukung merupakan alasan bahwa seseorang berkorban demi apa yang mereka kerjakan. Melalui nilai-nilai yang didukung ini, warga sekolah dapat mewujudkan fungsi dan tujuan sekolah sebagai suatu organisasi formal, selanjutnya asumsi yaitu simbolsimbol, nilai-nilai, keyakinan-keyakinan yang tidak dapat dikenali tetapi terus menerus berdampak terhadap perilaku warga sekolah.

Selanjutnya keyakinan dapat meraih prestasi adalah kekuatan yang dapat menyalakan harapan terus menyala. Artifak/ 
simbol, pesan, benda-benda, dokumen, kebiasaan dan sebagainya, diibaratkan seperti bahan bakar yang menyediakan energi agar mesin tetap hidup. Tenaga yang dihasilkan adalah "motivasi" yang terus bergerak. Semakin banyak bahan bakar keyakinan yang disalurkan, maka makin besar pula motivasi yang dihasilkan dan makin tinggi kinerja yang dicapai organisasi.

Hal tersebut diatas juga dikuatkan dengan hasil penelitian melalui pendekatan kuantitatif terhadap budaya sekolah yang mencakup, nilai dan keyakian, intimidasi dan individu, dan identitas/lingkungan fisik. Secara statistik deskriptif pada data aktual memiliki rentang nilai 149-210 dan rata-rata 184,35 yang lebih besar dari nilai median teoritis $=129$. Secara umum dari karakteristik sekolah menerangkan bahwa para guru menilai karakteristik budaya sekolah di Bali adalah baik. Jelantik (2015 : 291).

\section{Kinerja Guru Pendidikan Agama Hindu}

Kinerja diartikan sebagai sesuatu yang dicapai, hasil kerja atau prestasi yang diperlihatkan, kemampuan kerja, pelaksanaan, penyelenggaraan dan daya guna (Depdikbud, 1999 : 503). Bernardin dan Rusel (dalam Sianipar dan Entang, 2001 : 50) mendefinisikan bahwa kinerja adalah hasil yang diperoleh atas pelaksanaan suatu pekerjaan atau kegiatan tertentu dalam kurun waktu tertentu.

Sejalan dengan pendapat diatas, maka kinerja guru sangat erat kaitannya dengan prestasi yang dicapai dalam pelaksanaan tugas prestasinya sebagai gurumelaksanakan proses pembelajaran pendidikan agama Hindu; Untuk mencapai hal tersebut guru dituntut memiliki kompetensi sebagai kemampuan, kecakapan (ability), keterampilan dalam mengelola proses pembelajaran. Kompetensi merupakan persyaratan mendasar harus dimiliki seorang guru yang membuatnya berbeda dengan orang lain. Guru pendidikan agama Hindu wajib memiliki kualifikasi akademik, kompetensi, sertifikat pendidik sehat jasmani dan rohani, serta memiliki kemampuan untuk mewujudkan tujuan pendidikan agama Hindu dan tujuan pendidikan nasional. Sejalan dengan kewajiban tersebut seorang guru agar memiliki kompetensi pedagogik, keahlian dan keterampilan mengelola proses pembelajaran, kompetensi kepribadian, kompetensi sosial, dan kompetensi profesional, keahlian latar belakang pendidikan sesuai mata pelajaran yang diampunya.

Oleh karena tugas mendidik dan mengajar yang dilaksanakan oleh guru-guru di sekolah adalah suatu profesi maka untuk menjalankan tugas tersebut harus profesional mengacu pada pelaksanaan delapan standar nasional pendidikan yang meliputi, standar isi, proses, kompetensi lulusan, pendidikan dan tenaga kependidikan, sarana dan prasarana, pengelolaan, penilaian, dan pembiayaan dalam melaksanakan proses pembelajaran di sekolah (PP No.15 Tahun 2016; Pasal 2). Dalam pembelajaran berbasis kompetensi perlu ditentukan standar minimum kompetensi yang harus dicapai siswa. Dengan demikian kompetensi pokok pembelajaran berbasis kompetensi meliputi : (1) kompetensi yang akan dicapai, (2) strategi pencapaian untuk mencapai kompetensi, (3) sistem evaluasi atau pengujian yang digunakan untuk menentukan keberhasilan siswa dalam mencapai kompetensi.

Perumusan aspek-aspek kompetensi dilakukan dengan menganalisis kompetensi yang harus dicapai sesuai dengan kurikulum yang berlaku. Menurut KTSP Tahun 2006 kompetensi yang harus dikembangkan ada tiga aspek, masin-masing dengan tingkatan yang berbeda : (1) kompetensi afektif, yang 
menyangkut nilai, sikap, minat, apreasiasi, dan internalisasi, (2) kompetensi kognitif meliputi tingkatan pengetahuan pemahaman, aplikasi, analisis dan evaluasi, dan (3) kompetensi psikomotor meliputi keterampilan dan gerak. Sedangkan pada KTSP Tahun 2013 kompetensi yang harus dikembangkan pada peserta didik adalah empat aspek : (1) kompetensi spiritual, (2) kompetensi sosial, (3) kompetensi kognitif dan kompetensi psikomotor.

Memahami guru pendidikan agama Hindu adalah pendidik profesional dengan tugas utama mendidik, melatih, menilai dan mengevaluasi peserta didik. Maka guru harus mampu melaksanakan tugas secara profesional dan kinerjanya meningkat. Dengan demikian guru dituntut memiliki kemampuan dalam proses pembelajaran mulai dari merencanakan pembelajaran, melaksanakan pembelajaran, menilai hasil belajar, menganalisis hasil penilaian serta melaksanakan tindak lanjut hasil penilaian.

Berdasarkan paparan di atas guru-guru pendidikan agama Hindu diisyaratkan agar memiliki perilaku atau etos kerja tinggi dalam mewujudkan kinerjanya. Sinamo (2005:29) menyebutkan perilaku atau etos kerja merupakan kunci sukses sejati seperti : mampu bekerja tulus penuh syukur, mampu bekerja benar penuh tanggung jawab, mampu bekerja tuntas penuh integritas, mampu bekerja keras penuh semangat, mampu bekerja serius penuh kecintaan, mampu bekerja cerdas penuh kreativitas, mampu bekerja tekun penuh keunggulan, mampu bekerja paripurna penuh kerendahan hati. Selanjutnya Sinamo (2005) memformulasikan perilaku tersebut menjadi delapan etos kerja profesional yaitu: (1) kerja adalah rahmat (2) kerja adalah amerta, (3) kerja adalah panggilan, (4) kerja adalah aktualisasi, (5) kerja adalah ibadah, (6) kerja adalah seni, (7) kerja adalah kehormatan, (8) kerja adalah pelayanan.
Nilai-nilai tentang etos kerja yang termuat dalam tradisinya maupun dalam ajaran agamanya, bahwa kerja itu adalah merupakan kewajiban yadnya. Dalam mencapai Kesempurnaan, masyarakat Hindu percaya bahwa ada dua jalan yang bisa ditempuh yaitu, jalan ilmu pengetahuan (jaana) dan jalan kerja (yadnya) untuk memahami hakekat kerja, Bhagawagdita Sloka III.5 menyebbutkan sebagai berikut :

\section{Na hi kaśchit ksanam api Jātu tishthaty akarma-krt Kāryate hy avaśah karma Śārvah prakrtii-jair gunaih}

\section{Artinya}

Tidak seorangpun tidak bekerja menurut sifat-sifat yang telah diperolehnya dari sifat-sifat alam material, karena itu, tiada seorangpun yang dapat menghindari berbuat sesuatu, bahkan selama sesaat pun.

Kalau dikaji secara mendalam sloka tersebut menunjukkan dan mengajarkan bahwa manusia pada hakekatnya tidak bisa menghindari aktivitas tubuh, tindakan atau kerja, berfikir, berkata dan berbuat adalah merupakan tindakan dan aktivitas manusia. Hal tersebut harus dikelola secara profesional dalam bentuk yadnya dan persembahan untuk mencapai tujuan hidup kebahagiaan sekale dan niskale.

Dalam sloka III.8 Bhagawadgitha menyebutkan :

\section{Niyatam karu karma tvam \\ karma jyāyo hy akarmanah \\ śarira-yātrāpi ca te \\ na prasiddhyed akarmanah}

\section{Artinya :}

Lakukan tugas kewajibanmu yang telah ditetapkan, sebab melakukan 
demikian lebih baik dari pada tidak bekerja, seseorang tidak dapat memelihara badan jasmaninya pun tanpa bekerja.

Sloka di atas memberi petunjuk kepada guru-guru khususnya guru pendidikan agama Hindu dan seluruh masyarakat tentang etos kerja. Sloka tersebut juga memberi petunjuk tentang pekerjaan yang baik, hendaknya setiap orang bekerja sesuai bakat, minat dan kemampuannya. Setiap orang diharapkan tahu tentang makna dan arti dari suatu kerja, seperti yang disebutkan dalam Bhagawadgitha sloka IV.17 sebagai berikut :

Karmano hy api boddhavyam boddhavyam cha vikarmanah akarmanaś ca boddhyavyam gahanā karmano gatih

\section{Artinya :}

Seluk beluk perbuatan sulit sekali dimengerti, karena itu hendaknya seseorang mengetahui dengan sebenarnya apa arti perbuatan, apa arti perbuatan yang terlarang, dan apa arti tidak melakukan perbuatan.

Kalau direnungkan secara mendalam sloka tersebut memberi petunjuk kepada guru pendidikan Agama Hindu, harus mengerti perbedaan antara perbuatan, tidak melakukan perbuatan dan perbuatan yang tidak dibenarkan. Dengan demikian guru pendidikan Agama Hindu akan melaksanakan tugas secara professional didalam mengelola "proses pembelajaran" karena itu adalah bagian dari yadnya dalam menjalani kehidupannya.

Pelaksanaan pembelajaran merupakan implementasi dari rencana pelaksanaan pembelajaran yang telah dimodifikasi oleh guru untuk mencapai kompetensi yang telah ditetapkan. Hampir semua kecakapan, pengetahuan, keterampilan, kebiasaan, kegemaran dan sikap manusia terbentuk, dimodifikasi dan berkembang karena pembelajaran (Suryabrata, 1991).

Hal tersebut di atas sejalan dengan hasil penelitian melalui pendekatan kuantitatif terhadap kinerja guru pendidikan Agama Hindu yang mencakup, perencanaan pembelajaran, pelaksanaan pembelajaran, penilaian pembelajaran dan kualitas kinerja diperoleh gambaran bahwa kinerja guru pendidikan Agama Hindu tergolong baik. Hal ini dijelaskan secara statistik deskriptif pada data aktual memiliki rentang nilai 232 - 310 dan rata-rata 273,4 yang lebih besar dari nilai median teoritis $=186$, Data ini menunjukkan bahwa kinerja guru pendidikan agama Hindu tergolong baik. Jelantik (2015-2016).

\subsection{Penutup}

Dalam budaya sekolah yang baik, nilai-nilai yang disepakati dipegang secara mendalam dan dianut bersama secara meluas. Makin banyak warga sekolah yang menerima nilai-nilai tersebut budaya sekolah semakin kuat. Hal ini akan mempunyai pengaruh yang kuat terhadap perilaku guru karena tingginya tingkat kebersamaan dan intensitas akan menciptakan Ikliminternal atas pengendalian perilaku yang profesional. Budaya memiliki tapal batas dan identitas organisasi yang jelas. Budaya mempermudah timbulnya komitmen pada sesuatu yang lebih luas daripada kepentingan diri pribadi seseorang, budaya menetapkan sistem sosial, budaya merupakan perekat sosial yang membantu mempersatukan para guru dan stakeholder yang lain dengan memberikan standar yang tepat mengenai apa yang harus dilakukan para guru untuk meningkatkan kinerja guru pendidikan agama Hindu. 


\section{DAFTAR PUSTAKA}

Arikunto, S. 2006. Dasar-Dasar Evaluasi Pendidikan. Jakarta : Bumi Aksara.

Depdikbud. 1999. Karakteristik dan Prestasi Dalam Pendidikan. Jakarta : Direktorat Jenderal Pendidikan Dasar dan Menengah.

Jelantik, I Gusti Lanang. 2015. "Hubungan Kepemimpinan Hindu, Kecerdasan Emosional Guru, Supervisi Pengawas Sekolah, Budaya Sekolah, dan Motivasi Kerja Guru dengan Kinerja Guru Pendidikan Agama Hindu pada SMP Negeri di Provinsi Bali Tahun Ajaran 2013/2014". Desertasi (tidak diterbitkan). Denpasar : Pascasarjana Universitas Hindu Indonesia.

Peraturan Pemerintah Nomor 35 Tahun 2007 Tentang Pendidikan Agama dan Pendidikan Keagamaan. Jakarta : Departemen Pendidikan Nasional.

Rika, I Wayan. 2011. "Model Budaya Mutu pada Rintisan Sekolah Bertaraf Internasional di Provinsi Bali”.
Desertasi (tidak diterbitkan).

Malang : Pascasarjana

Universitas Negeri Malang.

Sianipar, I.P.G. dan A.M. Entang. 2001. Teknik-Teknik Analisis Manajemen. Jakarta : Lembaga Administrasi Negara- Republik Indonesia.

Sinamo, Jansen, 2005, 8 Etos Kerja Profesional Navigator Anda Menuju Sukses. Bogor : Grafika Mardi Yuwana.

Stolp, Stephen \& Smith, Stuartc. 1995. Transporming School Culture : Stories Symbols, Values and Leaders Role. Eugene, OR : Eric, Clearning House on Education Managemen University of Oregon.

Suryabrata, S. 1983. Psikologi Pendidikan. Yogyakarta : Grava Media.

Suyanto. 2001. Formula Pendidikan Nasional Era Global. Makalah disajikan dalam Forum Komunikasi Mahasiswa Program Pascasarjana UNM.

Widja, I Gede. 2012. Pendidikan Sebagai Geologi Budaya. Denpasar : Program Pascasarjana Universitas Udayana. 